\title{
Cestoda and Monogenea of some teleost fishes off the Mudanya Coast (Sea of Marmara, Turkey)
}

\author{
M. C. OGUZ ${ }^{1}$ R. A. BRAY ${ }^{2}$ \\ ${ }^{1}$ Biology Department, Faculty of Science and Arts, Ataturk University, Erzurum, Turkey, \\ E-mail: mcoguz@atauniedu.tr,m_c_oguz@hotmail.com; ${ }^{2}$ Department of Zoology, Natural History Museum,
} Cromwell Road, London Sw7 5BD, UK

\begin{abstract}
Summary
The following helminths are reported from the Sea of Marmara off the Mudanya coast. Cestoda: Didymobothrium rudolphii in Solea solea, Clestobothrium crassiceps in Merluccius merluccius, tetraphyllidean larvae in Gobius niger, G. cobitis, M. merluccius, Eutrigla gurnardus, $S$. solea, Scorpaena scrofa and Progrillotia dasyatidis in $G$. niger. Monogenea: Trochopus pini in E. gurnardus, Ligophorus confusus in Liza ramada, Tetraonchoides paradoxus in Uranoscopus scaber, Microcotyle mugilis in $L$. ramada and Anthocotyle merluccii in M. merluccius.
\end{abstract}

Key words: Cestoda, Monogenea, teleost fish, Sea of Marmara

\section{Introduction}

This is the third paper in which we document the parasitic helminths of teleost fishes in parts of the waterway connecting the Mediterranean and Black Seas. The first (Oguz \& Bray, 2006) reported 13 digeneans from fishes of the Sea of Marmara at Mudanya. The second (Keser et al. 2007) documented the cestodes, digeneans, nematodes and acanthocephalan from fishes caught in the Dardanelles strait at Çanakkale. These reports are of interest as they give further indications of the as the degree of invasion of individual species from the Mediterranean into the Black Seas. The Mediterranean harbours many more species of all groups than the Black Sea and our results begin to indicate at which points the nature of the fauna changes.

\section{Materials and methods}

The study area is in north western Anatolia, $40^{\circ} 22^{\prime} \mathrm{N}$, $28^{\circ} 52^{\prime} \mathrm{E}$ (see figure 1 in Oguz \& Bray, 2006). Between November 1990 and May 1993 between 6 and 28 specimens of 8 fish species were collected. The fish were placed in plastic containers containing seawater and transferred to the laboratory, where they were examined within 24 hours. Methods for necropsy and analysis were adapted from Pritchard \& Kruse (1982). All sites were examined for parasites with a stereomicroscope at x12 and x50 magnifications. Data for prevalence, intensity and abundance are given (Table 1.see Margolis et al. 1982). Specimens are deposited in Biology Department Faculty of Science and Art, Atatürk University, Erzurum, Turkey.

\section{Results}

\section{Cestoda}

Spathebothriidea

Acrobothriidae

Didymobothrium rudolphii (Monticelli, 1890)

Host: Solea solea

Infection site: Intestine.

Voucher specimen reference number: HWML 216123,216125

Remarks: This poorly studied tapeworm has internal serial repetition of reproductive systems, but no external segmentation. It is considered one of the primitive segmented cestodes. It is known mainly from the flatfishes Solea vulgaris, Pegusa impar, P. [Solea] lascaris and Lepidorhombus boscii in the Mediterranean, off Naples (Monticelli, 1890), the Saronic Gulf (Papoutsoglou, 1976) and off the mouth of the Tiber (Orecchia et al. 1985) and from the north eastern Atlantic off the Portuguese coast (Marques et al. 2006; Poddubnaya et al. 2006; Marques \& Cabral, 2007). Marques et al. (2007) reported that there are two cryptic species under this name in Pegusa lascaris off the Portuguese coast. As far as we are aware, D. rudolphii has not been reported in the Black Sea. 
Table 1. Helminth parasites of some fish species of Mudanya Coasts, Turkey. Number of examined fish (N), number of infected fish (In), prevalence (\%), range of intensity (M) and mean intensity (X), standard deviation ( \pm S.D.) and total $\left(\sum\right)$ number of parasite

\begin{tabular}{|c|c|c|c|c|c|}
\hline Host fish species & $\mathbf{N}$ & In \& (\%) & Identified parasite species & M \& (X \pm S.D.) & $\sum$ \\
\hline Gobius cobitis & 25 & $5(20.0)$ & Tetraphyllidean larva & $1-17(4.8 \pm 6.8)$ & 24 \\
\hline Gobius niger & 28 & $6(21.4)$ & Progrillotia dasyatidis & $1-3(2.1 \pm 0.8)$ & 13 \\
\hline Gobius niger & 28 & $3(10.7)$ & Tetraphyllidean larva & $2-15(6.6 \pm 7.2)$ & 20 \\
\hline Eutrigla gurnardus & 16 & $1(6.3)$ & Tetraphyllidean larva & $1(1.0 \pm 0)$ & 1 \\
\hline Eutrigla gurnardus & 16 & $1(6.3)$ & Trochopus pini & $1(1.0 \pm 0)$ & 1 \\
\hline Merluccius merluccius & 39 & $4(10.3)$ & Tetraphyllidean larva & $1-7(2.7 \pm 2.8)$ & 11 \\
\hline Merluccius merluccius & 39 & $5(12.8)$ & Clestobothrium crassiceps & $1-2(1.2 \pm 0.4) 1$ & 6 \\
\hline Solea solea & 56 & $6(10.7)$ & Tetraphyllidean larva & $2-4(2.5 \pm 1.3)$ & 15 \\
\hline Solea solea & 56 & $15(26.8)$ & Didymobothrium rudolphii & $4-22(8.1 \pm 4.9)$ & 122 \\
\hline Uranoscopus scaber & 16 & $10(62.5)$ & Tetraoncoides paradoxus & $1-15(7.0 \pm 3.9)$ & 70 \\
\hline Scorpaena scrofa & 17 & $1(5.9)$ & Tetraphyllidean larva & $1(1 \pm 0)$ & 1 \\
\hline Liza ramada & 18 & $16(88.9)$ & Ligophorus confusus & $3-10(5.6 \pm 2.1)$ & 90 \\
\hline Liza ramada & 18 & $1(5.5)$ & Microcotyle mugilis & $1(1 \pm 0) 1$ & 1 \\
\hline
\end{tabular}

Bothriocephalidea

Bothriocephalidae

Clestobothrium crassiceps (Rudolphi, 1819)

Host: Merluccius merluccius

Infection site: Intestine

Voucher specimen reference number: HWML 216124

Remarks: This is a common parasite of hake in the Mediterranean and north-eastern Atlantic and is reported from a wide variety of related fish over a wide distribution (see: www.nhm.ac.uk/host-parasite-database). Although the hake is found off the Anatolian coast of the Black Sea (Slastenenko, 1959), this parasite has not yet been reported there in this sea.

Tetraphyllidean larvae

Hosts: Gobius niger, G. cobitis, Merluccius merluccius, Eutrigla gurnardus, Solea solea, Scorpaena scrofa. Infection site: Intestine

Voucher specimen reference number: 9016MPTet 1-6

Trypanorhyncha

Progrillotiidae

Progrillotia dasyatidis Beveridge, Neifar \& Euzet, 2004 Host: Gobius niger

Infection site: Gall Bladder

Voucher specimen reference number: 9016MPTr 1- 5

Remarks: Identified using Palm (2004) and the description of the plerocerci by Marques et al. (2005). The plerocerci are characterized by the possession of 2 bothria, prebulbar organs and a heteroacanthous atypical armature, consisting of 6 principal solid hooks and a single row of $6-7$ uncinate intercalary hooks. The first principal hook is uncinate, followed by 4 falciform and a single uncinate hook $6\left(6^{\prime}\right)$ about half the size of hooks $5\left(5^{\prime}\right)$. The bulb ratio is below 8 .

\author{
Monogenea \\ Monopisthocotylea \\ Capsaloidea \\ Capsalidae
}

Trochopus pini (van Beneden \& Hesse, 1863)

Host: Eutrigla gurnardus

Infection site: Gill

Voucher specimen reference number: $9016 \mathrm{MPCa} 1$

Remarks: One specimen apparently belonging to the species $T$. pini was recovered. As far as we are aware the only report of a Trochopus from this host is that of Trochopus tubiporus (Diesing, 1836) in the Mediterranean Sea by Euzet et al. (1993). The species has been reported in several species of gurnard, from the north Atlantic and the Mediterranean Sea (Lawler, 1981; Radujkovic \& Euzet, 1989), but not in the Black Sea.

Dactylogyridea

Dactylogyridae

Ligophorus confusus Euzet \& Suriano, 1977

Host: Liza ramada

Infection site: Gill

Voucher specimen reference number: HWML216127

Remarks: This is a common parasite of Liza ramada in the Mediterranean Seas (see www.nhm.ac.uk/host-parasitedatabase), but, as far as we are aware, it has not been reported in the Black Sea. Altunel (1982) reported this host/parasite combination in the Turkish Aegean Sea.

Tetraocoidea

Tetraoncoididae

Tetraonchoides paradoxus Bychowsky, 1951

Host: Uranoscopus scaber 
Infection site: Gill

Voucher specimen reference number: HWML 216126

Remarks: This is a common parasite of $U$. scaber in the Mediterranean and Black Seas (see Euzet et al., 1993; Gaevskaya \& Dmitrieva, 1997).

Polyopisthocotylea

Microcotylidae

\section{Microcotyle mugilis (Vogt, 1878)}

Host: Liza ramada

Infection site: Gill

Voucher specimen reference number: 9016MPMi 1

Remarks: This species is a common parasite of L. ramada in the Mediterranean (Euzet et al. 1993, Radujkovic \& Euzet, 1989) and has recently been reported in the Black Sea in this host (Dmitrieva \& Gaevskaya 2001).

\section{Discocotylidae}

Anthocotyle merluccii (van Beneden \& Hesse, 1863)

Host: Merluccius merluccius

Infection site: Gill

Voucher specimen reference number: HWML216139

Remarks: This is a very widespread and common parasite of hakes (Merluccius spp.) in the Atlantic Ocean Basin, the south-western Indian Ocean and the eastern Pacific Ocean (see www.nhm.ac.uk/host-parasite-database). As far as we are aware it has not been reported in the Black Sea.

\section{Conclusions}

Oguz \& Bray (2006) found that only two of thirteen digenean species they reported in the Sea of Marmara were found in the Mediterranean Sea but not in the Black Sea. Keser et al. (2007) found that closer to the Mediterranean, in the Dardanelles, only one of eleven fully identified helminth species was (probably) not found in the Black Sea. Of the species reported in the present paper, several worms have not yet been found in the Black Sea, namely Didymobothrium rudolphii, Clestobothrium crassiceps, Progrillotia dasyatidis, Trochopus pini, Anthocotyle merluccii and Ligophorus confusus.

In the case of $C$. crassiceps and A. merluccii this is probably because their host, the hake Merluccius merluccius is rare and localized in the Black Sea (Slastenenko, 1959). A similar reason may account for the absence of records of D. rudolphii from the Black Sea, in that its host Solea solea only occurs, rarely, in the southwestern Black Sea.

\section{Acknowledgment}

We would like to thank Dr Oguz Ozturk, Afyon Kocatepe Unversity, for his kind help and Dr Harry Palm for identifying the trypanorhynch cestode.

\section{References}

Altunel, F. N. (1982): Seasonal changes and trematodes in mullet caught from the Aegean Sea. In Assistant Professors Thesis. Uludag: Uludag University, pp. 56.

DMitrieva, E. V., GaevsKaya, A. V. (2001): Parasitological aspects of mugilids mariculture and of their introduction to the Sea of Asov and the Black Sea. Ekologiya Morya, Kiev, 55, 73 - 78 (In Russian).

Euzet, L., Combes, C., CARO, A. (1993): A check-list of monogenean of Mediterranean fish. Report of the Second International. Symposium on Monogenea, 5 - 8 July 1993, Montpellier/Sète, France, 20 pp.

Gaevskaya, A. V., DMitrieva, E. V. (1997): Overview of Black Sea monogenean fauna. Ekologiya Morya, Kiev, 46: 7 - 16 (In Russian).

Keser, R., Bray, R. A., Oguz, M. C., Çelen, S., ERdoĞAn, S., DoĞUTURK, S., AKlanoĞLU, G., Marti, B. (2007): Endohelminths of some teleost fish caught in the Dardanelles at Çanakkale, Turkey. Helminthologia, 44, $217-221$

LAWLER, A. R. (1981): Zoogeography and host-specificity of the subfamily Capsaloidea Price, 1936 (Monogenea: Monopisthocotylea). Special Papers in Marine Science, 6: $\mathrm{xxV}+650 \mathrm{pp}$.

Margolis, L., Esch, G. W., Holmes, J. C., Kuris, A. M., SCHAD, G. A. (1982): The use of ecological terms in parasitology (report of an ad hoc committee of the American Society of Parasitologists). J. Parasitol., 68, 131 - 133

MARQUES, J. F., CABRAL, H. N. (2007): Effects of sample size on fish parasite prevalence, mean abundance and mean intensity estimates. J. Appl. Ichthyol., 23, $158-162$

Marques, J. F., Santos, M. J., Cabral, H. N., Palm, H. W. (2005): First record of Progrillotia dasyatidis Beveridge Neifar and Euzet, 2004 (Cestoda: Trypanorhyncha) plerocerci from teleost fishes off the Portuguese coast, with a description of the surface morphology. Parasitol. Res., 96, 206 - 211 DOI: 10.1007/s00436-005-1341-7.

Marques, J. F., SAntos, M. J., Gibson, D. I., Cabral, H. N., Olson, P. D. (2007): Cryptic species of Didymobothrium rudolphii (Cestoda: Spathebothriidea) from the sand sole Solea lascaris off the Portuguese coast with an analysis of their molecules morphology ultrastructure and phylogeny. Parasitology, 134, 1057 - 1072 DOI: 10.1017/S0031182007002491

Marques, J. F., TeiXeira, C. M., CABral, H. N. (2006): Differentiation of commercially important flatfish populations along the Portuguese coast: evidence from morphology and parasitology. Fish. Res., 81, 293 - 305

Monticelli, F. S. (1890): Note elmintologiche. Bollettino della Società di Naturalisti in Napoli, Serie 1, 4, 189 208.

OguZ, M. C., BRAY, R. A. (2006) : Digenetic trematodes of some teleost fish off the Mudanya Coast (Sea of Marmara, Turkey). Helminthologia, 43, $161-167$ 
Orecchia, P., Paggi, L., Minervini, R., Di Cave, D. (1985): La parassitofauna delle specie ittiche strascicabili presenti alla foce del fiume Tevere. Oebalia, 11, 623-632

Palm, H. W. (2004): The Trypanorhyncha Diesing, 1863. Bogor: PKSPL-IPB Press, 710 pp.

PAPOUTSOGLOU, S. E. (1976): Metazoan parasites of fishes from Saronicos Gulf Athens - Greece. Thalassographica, $1,69-102$

Poddubnaya, L. G., Gibson, D. I., Świderski, Z., Olson, P. D. (2006): Vitellocyte ultrastructure in the cestode Didymobothrium rudolphii (Monticelli, 1890): possible evidence for the recognition of divergent taxa within the Spathebothriidea. Acta Parasitol., 51, 255 - 263

Pritchard, M. H., Kruse, G. O. W. (1982): The collection and preservation of animal parasites. Technical Bulletin No 1. University of Nebraska Press, Lincoln and London, 141pp.

RadujKovic, B. M., Euzet, L. (1989): Parasites des poissons marins du Montenegro: Monogenes. Acta Adriat. $30,51-135$.

SLASTENENKO, E. P. (1959): Zoogeographical review of the Black Sea fish fauna. Hydrobiologia, 14, $177-188$ 